\title{
Design of Smart Medical Mask Trash Can For Public Places
}

\author{
$1^{\text {st }}$ Muhammad Dhafier Mu'afa \\ Faculty of Engineering \\ Universitas Sebelas Maret \\ Surakarta, Indonesia \\ dhafier@student.uns.ac.id
}

\author{
$4^{\text {th }}$ Muhammad Fiqih Al Faishal \\ Faculty of Engineering \\ Universitas Sebelas Maret \\ Surakarta, Indonesia \\ mfiqih.alfaishal@student.uns.ac.id
}

\author{
$2^{\text {nd }}$ Refansyah Basu Dewa \\ Faculty of Engineering \\ Universitas Sebelas Maret \\ Surakarta, Indonesia \\ refansyah_dewa@student.uns.ac.id
}

\author{
$3^{\text {rd }}$ Muhammad Raflie Pangestu \\ Faculty of Engineering \\ Universitas Sebelas Maret \\ Surakarta, Indonesia \\ rafliepangestuuu@student.uns.ac.id
}

\author{
$5^{\text {th }}$ Hari Maghfiroh, M.Eng. \\ Faculty of Engineering \\ Universitas Sebelas Maret \\ Surakarta, Indonesia \\ hari.maghfiroh@staff.uns.ac.id
}

\begin{abstract}
The Covid-19 pandemic mainly caused the sudden rise of medical mask waste. There are some steps that can be taken to reduce and manage the waste, including dissolving the mask so it cannot be use again, reduce the risk of disease transmission, and assist the workers in managing the waste of medical mask. Therefore, this paper proposes a device that can solve all the problem, which is the "Smart Medical Mask Trash Can". This device can be used to dissolve and disinfect the mask, as well as manage the mask waste with an easy way in accordance with health protocol. The outcome show that this device can monitor the waste with an application program on a real time that can notify and organize a schedule for automatic disinfection. This tool is suitable to be placed in public places because of its high mobility and there is a lot of medical mask's waste.
\end{abstract}

Keywords- Medical Mask, Waste, Dissolve, Health Protocol.

\section{INTRODUCTION}

The need for a supply of medical masks in Indonesia is very high considering that Indonesia is one of the most populous countries in the world. The current Covid-19 pandemic has also caused the need for medical masks to increase in Indonesia. Keeping in mind that the use of medical masks is only disposable or cannot be used repeatedly, this will lead to the accumulation of medical mask waste. Poor management of medical mask waste can cause several problems. The problem is the collection and resale of used medical masks by irresponsible parties because used medical masks are often found intact. Another problem is the increased risk of disease transmission from bacteria/viruses attached to used masks.

The World Health Organization (WHO) continues to remind the importance of proper use, storage and disposal of masks to ensure the best effectiveness of masks and to avoid increasing the risk of disease transmission. Based on the guidelines issued, WHO prohibits the reuse of single-use masks [1]. Disposable masks cannot be used repeatedly because the harmful particles filtered out by disposable masks will not disappear if they do not damage the components of the mask [2]. In addition, the effectiveness of single-use masks will continue to decrease if they are used repeatedly [3].

There are several steps that can be taken to reduce the risk of reuse and transmission of used masks. The Directorate of Environmental Health of Indonesia (2020) has issued guidelines for the management of mask waste from the public. These steps are collecting masks used, disinfecting masks, changing the shape of masks so they cannot be used, throwing them in the domestic trash, and washing hands [4]. The Directorate of Environmental Health of Indonesia (2020) also states that mask waste must be separated from other waste and collected at least once every 6 hours or when the shelter has been filled by $3 / 4$ of the total capacity during the Covid-19 pandemic [5].

Judging from the existing problems and with the guidelines provided, a practical device is needed that can simplify the waste management process and prevent the use and re-circulation of single-use masks. Trash cans made to collect used disposable masks from the general public. The mask shredding machine will turn on automatically if someone is detected throwing the mask away. The crushed masks will be placed in a storage at the bottom of the trash can. The mask waste in the storage will be sprayed with disinfectant liquid so that it can reduce the risk of disease transmission. This trash can is also equipped with the monitoring system of medical mask waste management. There is monitoring of mask waste collection capacity and monitoring of mask waste disposal schedules in accordance with the guidelines of the Ministry of Health of the Republic of Indonesia. The monitoring system in this trash can is based on the Internet of Things (IoT) where the trash can manager can receive information on the disposal schedule and the capacity of the mask waste storage via smartphone.

\section{TECHNICAL APPROACH}

\section{A. Medical Mask Shredder}

The shredding machine is used to crush/tear used medical masks until they cannot be reused. The concept of a mask shredding machine is actually the same as a paper shredder. The type of machine used is a crusher. The crushing machine holds the material between two solid surfaces that are arranged in parallel or that are in close contact with each other, and exerts a force to carry the material through it, using enough energy to crush the material so that the molecules separate (break), or deformation occurs (deformation) [6]. A few modifications were made so that the machine can destroy disposable masks, which are quite strong in structure. Modifications were made to optimize and improve the functionality of the shredder [7]. 
The medical mask shredder will be driven by an AC $220 \mathrm{~V}$ motor. An electric motor is a device for converting electrical energy into mechanical energy. AC motor is an electric motor that is driven by alternating current (AC). Generally, an AC motor consists of two main components, namely a stator and a rotor. The stator is a component of static electricity. The rotor is a rotating electrical component to rotate the motor axle. The type of motor used is a singlephase induction motor. This motor has only one stator winding, operating with a single-phase power supply, has a squirrel-cage rotor, and requires a device to start the motor [8].

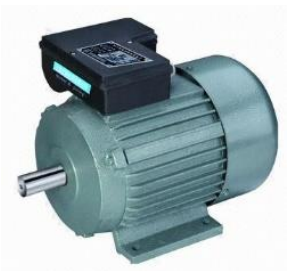

Fig. 1 AC 220V Motor

\section{B. Microcontroller Component}

In this paper, two microcontrollers are used that function for an automatic mask shredding system and a mask waste monitoring system:

\section{Arduino UNO R3:}

Arduino UNO is one of the most popular microcontrollers because of its easy operation. Arduino UNO is a board based on the microcontroller on the ATmega328. This board has 14 digital input/output pins (of which 6 can be used as PWM outputs), 6 analog inputs, $16 \mathrm{MHz}$ crystal oscillator, USB connection, reset button power jack. These pins contain everything needed to support the microcontroller [9].

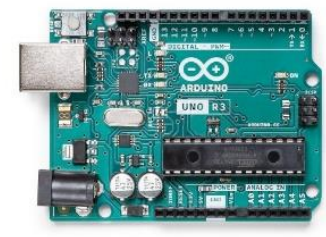

Fig. 2 Arduino UNO R3

\section{NodeMCU Esp8266:}

NodeMCU is an electronic board based on the ESP8266 chip with the ability to run microcontroller functions and also an internet connection (WiFi). There are several I/O pins so that they can be developed into a monitoring and controlling application for IoT projects [10].

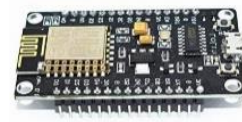

Fig. 3 NodeMCU Esp8266

\section{Sensor Component}

Ultrasonic sensors are used to detect the disposed masks to turn on the shredding machine and monitor the capacity of the mask waste collection. The ultrasonic sensor type HCSR04 is a device used to measure the distance from an object. The range of the measurable distance is about 2-
$450 \mathrm{~cm}$. This device uses two digital pins to communicate the read distance. The working principle of this ultrasonic sensor works by sending an ultrasonic pulse of about 40 $\mathrm{KHz}$, then it can reflect the echo pulse back, and calculate the time taken in microseconds [11].

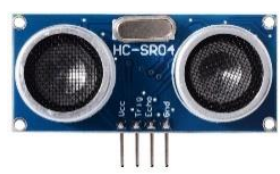

Fig. 4 Ultrasonic Sensor HC-SR04

\section{Another Component}

Relay:

The relay is used as a switch to turn on the water pump to turn on the automatic disinfectant sprayer and to turn on the motor to drive the shredder. Relay is a simple electronic circuit and consists of a switch, an electromagnetic field (coil wire), and an iron shaft. The function of the relay is to disconnect or connect one electronic circuit to another electronic circuit or is a type of electromagnetic switch [9].

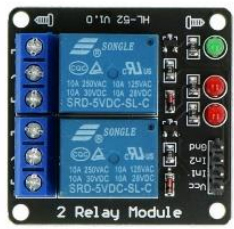

Fig. 5 5V Relay Module

\section{V Water Pump:}

The water pump is a component used to spray disinfectant liquid into the mask waste. The working principle is that the disinfectant liquid is pulled out of its place and released through the hose to the mask waste. The liquid will be converted into mist form by the nozzle sprayer.

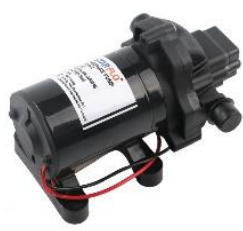

Fig. 6 12V Water Pump

\section{E. Workflow}

This device consists of two systems, namely the shredding of masks and monitoring system for the mask waste storage. The mask waste monitoring system consists of scheduled automatic disinfectant spraying, scheduled waste disposal system, and monitoring the capacity of the waste storage. The shredding mask system controlled by Arduino $\mathrm{UNO}$, and the monitoring system for the mask waste storage controlled by NodeMCU Esp8266 connected to smartphone via $\mathrm{WiFi}$ and Blynk App. 
SHREDDING THE MASK

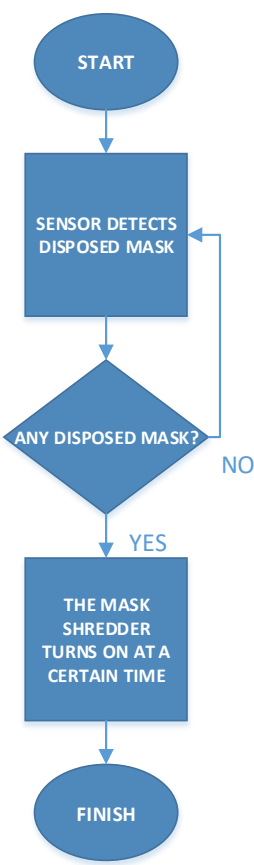

Fig. 7 Mask Shredding Workflow

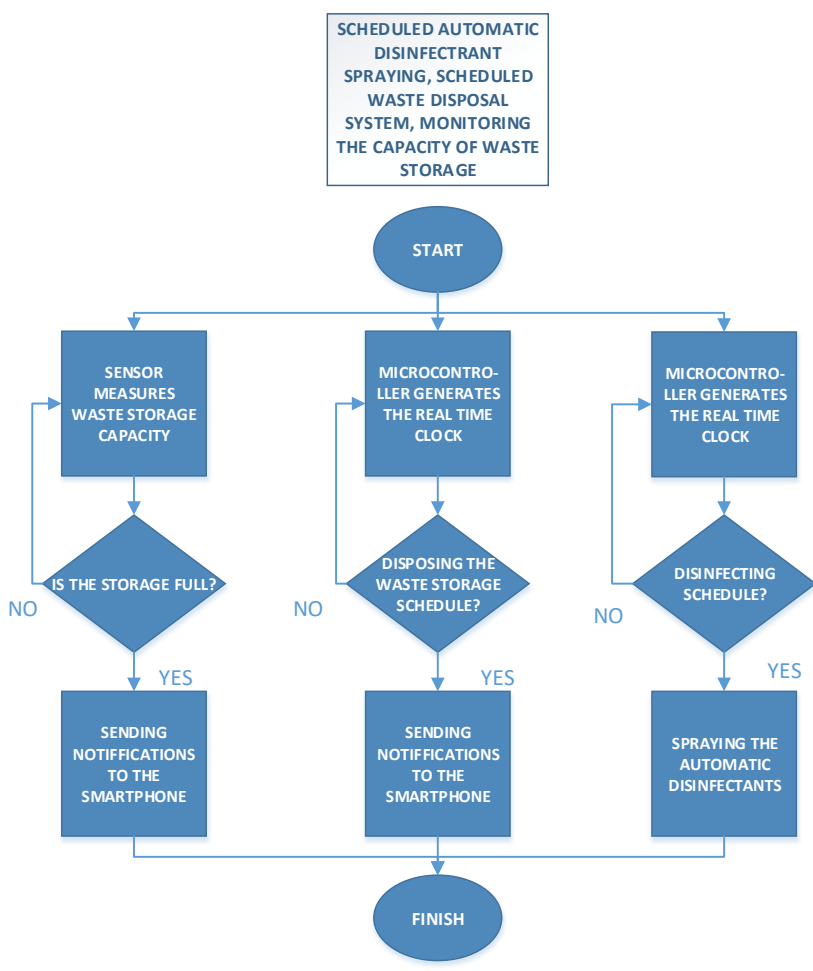

Fig. 8 Waste Storage Monitoring Workflow

\section{F. Component Wiring}

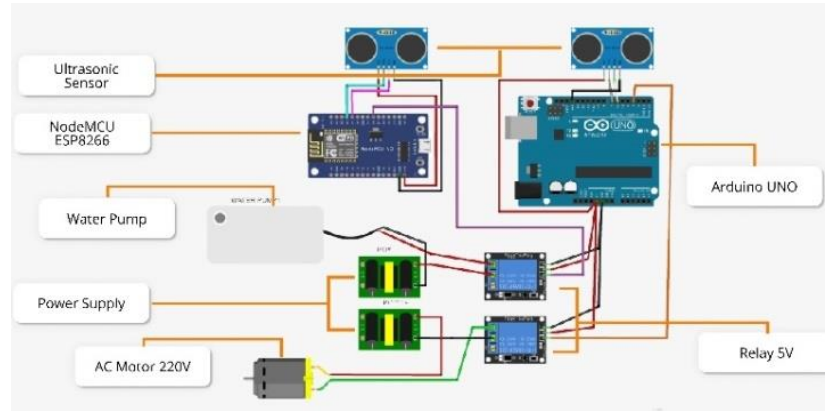

Fig. 9 Component Wiring

\section{DESIGN AND IMPLEMENTATION}

The creation of this trash can starts from the design that is used as a reference in implementation. The design carried out is a 3D design of the frame and casing of the trash can as an illustration of the placement of the trash can in the implementation, placing the components that make up the trash can, and seeing the workflow of this device. After the design is successfully created, the next step is to implement it into a real object. The manufacturing steps consist of making the frame of the trash can, making the casing of the trash can, assembling the shredder machine, making the system of the trash can, and evaluating the performance.

\section{A. Design}

Fig. 10 is the 3D design of the Smart Medical Mask Trash Can. There is a frame and the casing of the trash can. The shredder machine is driven by an AC $220 \mathrm{~V}$ motor located at the top of the trash can. The mask will be put into a shredding machine where the results will be stored at the bottom of the trash can. In addition, the mask waste will be sterilized by an automatic disinfectant sprayer. At the top there is a hole for inserting the mask waste. The hole has direct access to the shredding machine, so the mask can be crushed immediately. The front of the trash can may be opened like a door, so that the trash can manager can easily dispose the mask waste.

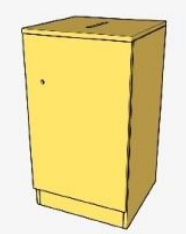

Fig. 10 Body of Smart Medical Mask Trash Can

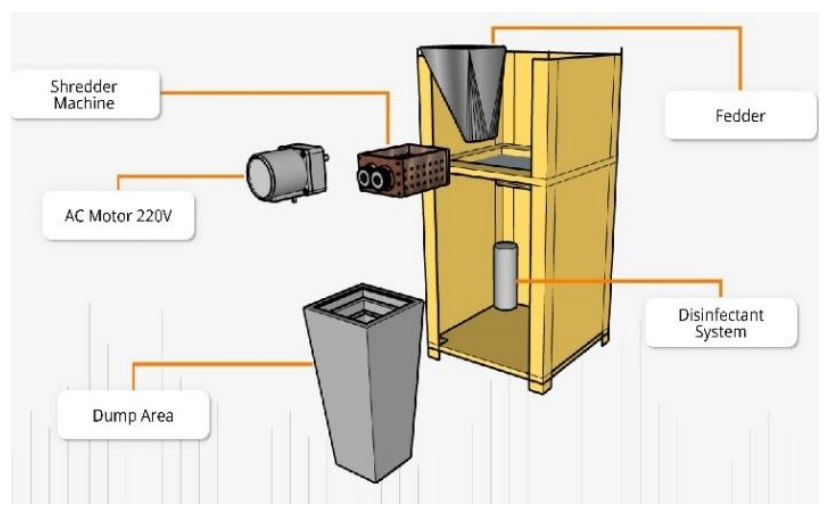

Fig. 11 Structure of Smart Medical Mask Trash Can 
Fig. 12 shows the structural design of the shredding machine. The shredding machine consists of several parts which are explained in Table 1. The shredding machine will be driven by a $220 \mathrm{~V}$ AC motor. The mask waste is in the middle of the cutting eye which will then change the shape of the mask.

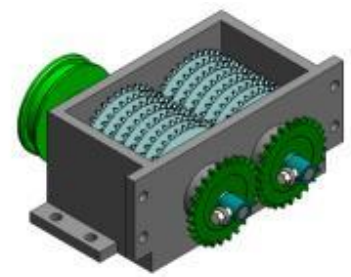

Fig. 12 3D Design of Medical Mask Shredder

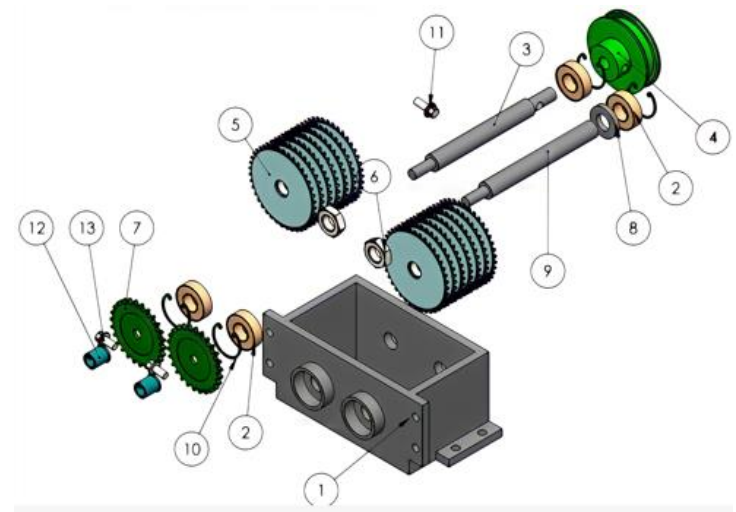

Fig. 13 Part of Medical Mask Shredder

TABLE I. PART OF MASK SHREDDER

\begin{tabular}{|c|c|}
\hline Part (Item Number) & Quantity \\
\hline Box (1) & 1 \\
\hline Bearing (2) & 4 \\
\hline As D2 21 (3) & 1 \\
\hline Pulley (4) & 1 \\
\hline Cutter D4 (5) & 14 \\
\hline $\begin{array}{c}\text { B18.2.4M-Hex Jam Nut, } \\
\text { M.20x2.5 --W-C (6) }\end{array}$ & 16 \\
\hline Gear (7) & 2 \\
\hline Ring (8) & 1 \\
\hline As D2 19 (9) & 1 \\
\hline Snap Ring (10) & 4 \\
\hline $\begin{array}{c}\text { B18.6.7M-M8x1.25x20 } \\
\text { Plain HFMS--20N (11) }\end{array}$ & 1 \\
\hline Gear Lock (12) & 2 \\
\hline $\begin{array}{c}\text { B18.6.7M-M8x1.25x16 } \\
\text { Plain HFMS--16N (13) }\end{array}$ & 2 \\
\hline
\end{tabular}

\section{B. Implementation}

Implementation is carried out based on the design that has been made. The implementation of the body of the trash can can be seen in the Fig. 14.

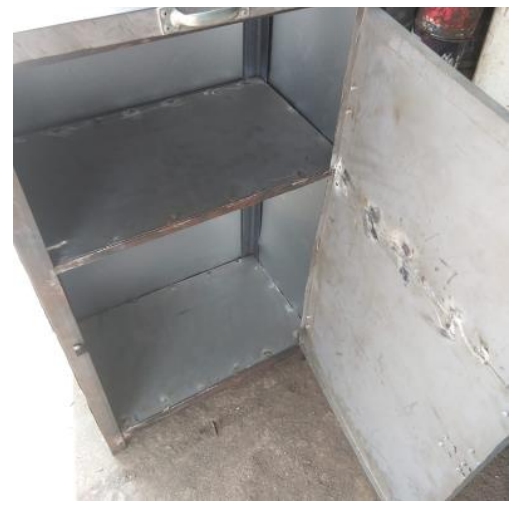

Fig. 14 Body of Smart Medical Mask Trash Can

Then the manufacture and assembly of a mask shredder machine. The result can be seen in Fig. 15.

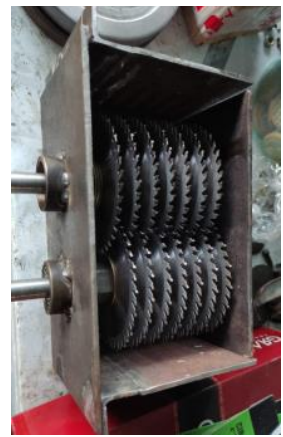

Fig. 15 Mask Shredder Machine

\section{EXPERIMENT AND RESULT}

The physical appearance of the 'Medical Mask Trash Can' can be seen in Fig. 16. At the top of the trash can, there is a $220 \mathrm{~V}$ AC motor, mask shredder machine, Arduino UNO, 5V relay, and ultrasonic sensor HC-SR04. At the bottom there is a mask waste collection, automatic disinfectant system, ultrasonic sensor HC-SR04, NodeMCU Esp8266, and a 5V relay.

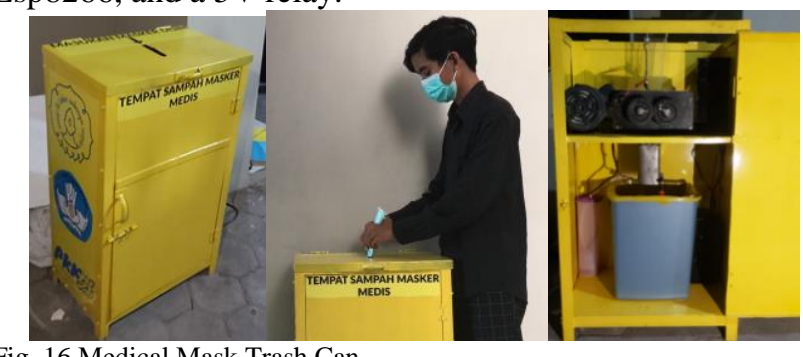

Fig. 16 Medical Mask Trash Can

In running the Medical Mask Trash Can system, two microcontrollers are used, namely NodeMCU Esp8266 and Arduino UNO R3. NodeMCU Esp8266 is used to monitor the capacity of mask waste collection, scheduling automatic disinfectant liquid distribution for mask waste, scheduling mask waste disposal, and connect the trash can with the manager's smartphone. Arduino UNO R3 is used to identify wasted masks to run the $220 \mathrm{~V}$ AC motor automatically as a driver for the mask shredder machine.

The shredder will be driven by a $220 \mathrm{~V}$ AC motor. The motor will turn on when the ultrasonic sensor HC-SR04 detects a wasted mask. If this sensor detects a wasted mask at a certain distance, the motor will be energized by an 
electric current which is accommodated by the $5 \mathrm{~V}$ relay module which causes the motor to rotate. This system uses Arduino UNO R3 microcontroller.

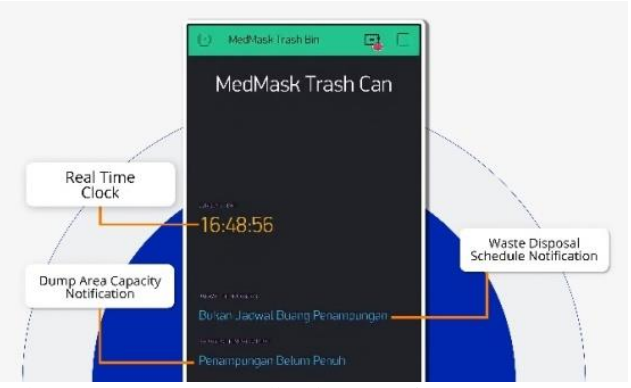

Fig. 17 Trash Can Manager's Application Interface

Fig. 17 is an application interface for the Medical Mask Trash Can manager. Applications are built on the Blynk platform and connected to the NodeMCU Esp8266. Features in this application include the appearance of the clock in real time, notification of the schedule for disposing of mask waste, and monitoring the capacity of the mask waste storage.

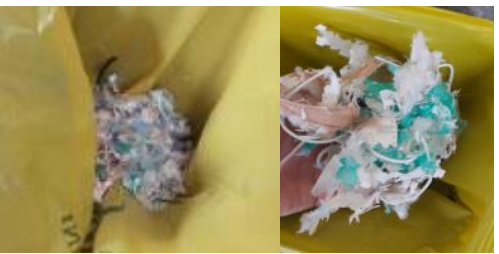

Fig. 18 Shredded Mask

Fig. 18 shows the shredded mask waste. Mask waste is accommodated in a container that is ready to be moved or disposed. The capacity of the mask waste collection is controlled by the ultrasonic sensor HC-SR04. In addition, the mask waste will be sprayed with disinfectant liquid automatically.

\section{TABLE II. MASK SHREDDING TIME EXPREIMENT}

\begin{tabular}{|c|c|}
\hline Attempt & Shredding Time (s) \\
\hline Mask 1 & 13.5 \\
\hline Mask 2 & 13.2 \\
\hline Mask 3 & 13.45 \\
\hline Mask 4 & 12.2 \\
\hline Mask 5 & 10.98 \\
\hline Mask 6 & 12.34 \\
\hline Mask 7 & 11.07 \\
\hline Mask 8 & 13.33 \\
\hline Mask 9 & 12.11 \\
\hline Mask 10 & 10.81 \\
\hline Mask 11 & 12.46 \\
\hline Mask 12 & 14 \\
\hline Mask 13 & 13.29 \\
\hline Mask 14 & 13.67 \\
\hline Mask 15 & 12.92 \\
\hline Mask 16 & 13.4 \\
\hline Average Time & 12.670625 \\
\hline
\end{tabular}

\section{Mask Shredding Time Expreriment}

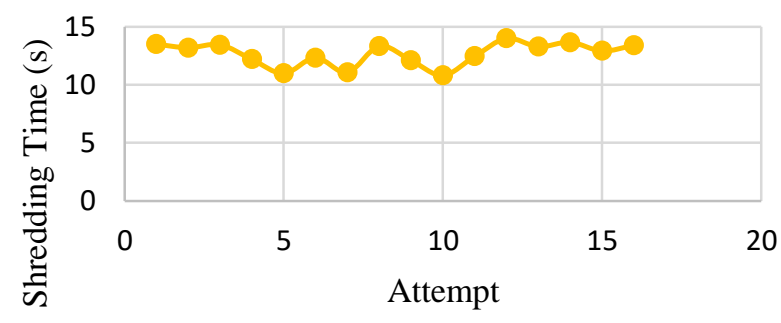

Fig. 19 Mask Shredding Time Experiment

Table 2 shows the shredding time of a medical mask that is inserted into the Smart Medical Mask Trash Can. The shredding time is calculated from the masks starting to be destroyed until the results are fully entered into the waste storage. Based on the experiments conducted, the results obtained that the average time of shredding a medical mask is 12.670625 seconds.

\section{CONCLUSION}

Smart Medical Mask Trash Can is expected to be implemented and used continuously. This trash can is expected to provide convenience in the disposal of masks for the general public, and can provide convenience in medical mask waste management. With an adequate number of trash cans, the general public can dispose of mask waste easily without the need to crush and sterilize the masks. In addition, this trash can is also expected to facilitate medical waste management, because the discarded masks have been collected in a container that are ready to be disposed, and masks that have been crushed and sterile according to the guidelines from the Ministry of Health of the Republic of Indonesia.

\section{ACKNOWLEDGMENT}

The author would like to thank the Ministry of Education, Culture, Research, and Technology of Indonesia who support this project through Program Kreativitas Mahasiswa Karsa Cipta (PKM-KC) funding. The author also to thank you to the UNS academic community who have supported and provided many suggestions to the author.

\section{REFERENCES}

[1] World Health Organization. 2020. "Pembersihan Dan Disinfeksi Permukaan Lingkungan Dalam Konteks COVID-19." https://www.who.int/docs/defaultsource/searo/indonesia/covid19/pembersihan-dandisinfeksi-permukaan-lingkungan-dalam-kontekscovid-19.pdf?sfvrsn=2842894b_2.

[2] National Academies of Sciences Engineering Medicines. 2006. "Reuse of Disposable Medical Masks During Flu Pandemic Not Recommended; Reusing Respirators Is Complicated.” Washington.

[3] Xi, Jinxiang, Xiuhua April Si, and Ramaswamy Nagarajan. 2020. "Effects of Mask-Wearing on the Inhalability and Deposition of Airborne SARS-CoV2 Aerosols in Human Upper Airway." Physics of 
https://doi.org/https://doi.org/10.1063/5.0034580.

[4] Direktorat Kesehatan Lingkungan. 2020. "Pedoman Pengelolaan Limbah Masker Dari Masyarakat." https://covid19.kemkes.go.id/download/Pedoman_Ke lola_Limbah_Masker_Masyarakat.pdf.

[5] Direktorat Kesehatan Lingkungan. 2020. "Pedoman Pengelolaan Limbah Rumah Sakit Rujukan, Rumah Sakit Darurat, Dan Puskesmas Yang Menangani Pasien Covid-19."

[6] Mulyadi. 2019. “Analisa Unjuk Kerja Mesin Pencacah Limbah Botol Plastik Dan Soft Drink Dengan Kapasitas $10 \mathrm{Kg} / \mathrm{Jam} . " \quad$ Universitas Muhammadiyah Sumatera Utara.

[7] Kurniawan, Heri; Margianto; Robbi, Nur. 2021. "Analisis Gearbox Pada Modifikasi Mesin Pencacah Kertas Dengan Pisau Zig-Zag." Jurnal Nasional Teknik Elektro 16 (2).

[8] Sofiah, and Yosi Apriani. 2019. "Pengaturan Kecepatan Motor AC Sebagai Aerator Untuk Budidaya Tambak Udang Dengan Menggunakan Solar Cell.” Jurnal Ampere 4 (1): 209-21.

[9] Rahardi, Riyan, Dedi Triyanto, and Suhardi. 2018. "Perancangan Sistem Keamanan Sepeda Motor Dengan Sensor Fingerprint, SMS Gateway, Dan GPS Tracker Berbasis Arduino Dengan Interface Websitse." Jurnal Coding, Sistem Komputer Untan 6 (3): 118-27.

[10] Efendi, Mohamad Yusuf, and Joni Eka Chandra. 2019. "Implementasi Internet of Things Pada Sistem Kendali Lampu Rumah Menggunakan Telegram Messenger Bot Dan Nodemcu Esp 8266." Global Journal of Computer Science and Technology: AHardware \& Computation 19 (1): 1-12.

[11] Puspasari, Fitri, Imam Fahrurrozi, Trias Prima Satya, Galih Setyawan, Muhammad Rifqi Al Fauzan, and Estu Muhammad Dwi Admoko. 2019. "Sensor Ultrasonik HCSR04 Berbasis Arduino Due Untuk Sistem Monitoring Ketinggian." Jurnal Fisika Dan Aplikasinya 15 (2): 36-39. 